\title{
Histological and Histochemical Studies on the Early Developmental Stages of the Egyptian Toad Bufo regularis Reuss
}

\author{
Alaa El-Din H. Sayed ${ }^{1}$, Afaf I. Elballouz ${ }^{1,2}$, Ekbal T. Wassif ${ }^{1}$ \\ ${ }^{1}$ Zoology Department, Faculty of Science, Assiut University, Assiut, Egypt \\ ${ }^{2}$ Zoology Department, Faculty of Science, Misurate University, Misurate, Libya \\ Email: ${ }^{*}$ alaa_h254@yahoo.com
}

Received 11 February 2015; accepted 30 March 2015; published 3 April 2015

Copyright (C) 2015 by authors and Scientific Research Publishing Inc.

This work is licensed under the Creative Commons Attribution International License (CC BY). http://creativecommons.org/licenses/by/4.0/

(c) (i) Open Access

\begin{abstract}
The present study was carried out to investigate the histological and histochemical changes in the liver and skin on different developmental stages of Egyptian toad Bufo regularis to be used as a histological key for such species. Our experiment started when tadpoles began to feed. The adapted embryos are divided into 3 large tanks of 200 embryos each, collections of samples started from feeding age every three days. Both histological and histochemical results showed that the general architecture of the different organs was correlated with the state of development, i.e. larval, metamorphic and post-metamorphic. They, therefore, displayed different characteristic features depending on the investigated developmental stage starting from the larval stage (stage 44) and ending with the post-metamorphic stage 66.
\end{abstract}

\section{Keywords}

Anura, Metamorphosis, Histology, Bufo regularis, Apoptosis

\section{Introduction}

Histological changes have been widely used as biomarkers, both in the laboratory [1] [2], and field studies [3]. One of the great advantages of using histological biomarkers in environmental monitoring is that this category of biomarkers allows examining specific target organs, including gills, kidney and liver, which are responsible for vital functions, such as respiration, excretion and the accumulation and biotransformation [4].

The liver plays an indispensable part in many processes in the body, particularly those concerned with its me-

${ }^{*}$ Corresponding author.

How to cite this paper: Sayed, A.H., Elballouz, A.I. and Wassif, E.T. (2015) Histological and Histochemical Studies on the Early Developmental Stages of the Egyptian Toad Bufo regularis Reuss. Open Journal of Animal Sciences, 5, 142-156. 
tabolism (e.g., protein synthesis, storage metabolites, bile secretion and detoxification). On the other hand, it plays important roles in the conversion of glucose to glycogen, regulation of lipids and deamination of amino acids. It is the organ in which nutrients absorbed in the digestive tract are processed and stored for use by other parts of the body. Also, liver is a target of cytological modifications caused by changes in the lifestyle, once the aquatic omnivorous tadpole changes to a terrestrial carnivorous adult [5].

Among many metabolic pathways, the liver is the site for the ornithine or urea cycle, which is an enzyme system that converts ammonia into urea [6]. Ammonia, produced from protein catabolism, is toxic to higher animals and must be excreted or detoxified [6]. Aquatic amphibians and larvae excrete ammonia are via the gills, but most adult terrestrial amphibians are ureotelic. The induction of the ornithine cycle at metamorphosis enables the con-version of ammonia into urea [6].

The histological structure of the amphibian liver is similar to that in other vertebrates [7], with hepatocytes arranged in clusters and cords separated by a meshwork of sinusoids and the presence of the traditional triad of portal venule, hepatic arteriole, and bile duct. The lobular pattern is less distinct than in mammals [7] [8]. The sinusoids are capillary networks and are localized in the space among hepatic plates in which hepatocytes are arranged [9].

During amphibian metamorphosis, dramatic changes in morphogenesis and differentiation of epidermis occur under the influence of hormones [10]. Among the various tissues, skin is an especially interesting example because the tissue develops adult skin in the body region and histolyzes larval skin in the tail region during metamorphosis [10]. Since the earlier transplantation experiments of Lindeman [11] [12], it has been believed that the regional specificity of tadpoles skin is intrinsically determined in the constituent cells prior to metamorphosis [13].

Development, function, remodeling and senescence of multicellular organisms depend on the coordinated occurrence of actively induced cell death in two major patterns: terminal differentiation often considered as physiological cell death (diffpoptosis) and programmed cell death or apoptosis [14]. Amphibian metamorphosis provides an excellent model for studying these two types of cell death. Keratinization or terminal differentiation of body epidermis can serve as a useful model of physiological cell death and tail tissue regression serves as a model of apoptosis [10].

A major difference between the tadpole and frog skin is that all cells in the tadpole epidermis replicate while only the basal cells replicate in frog skin [15]. The germinal layer replication is characteristic of the epidermis of all adult vertebrate species while the self-replicating tadpole epidermis resembles the mammalian fetal skin called the periderm [15].

The present work aimed to study the histological and histochemical changes of the Egyptian toad Bufo regularis during development and metamorphosis, and this search might be considered as a histological key for these species.

\section{Material and Methods}

\subsection{Experimental Design}

The adapted embryos were described according to [16] and selected according to [17] subdivided into 3 large tanks (200 embryos per each). The conditions of the experiment were the same as that of acclimatization with daily changing all the tap water. Counting of the dead samples occurred every day to calculate the mortality rate. Twenty tadpoles were taken every three days during the experimental period for the different proposed studies. Some of tadpoles were fixed in Bouin's fixative or 10\% buffered formalin and others were fixed in Davidson' solution [33 ml ethanol alcohol (95\%), $25 \mathrm{ml}$ formalin, $11.5 \mathrm{ml}$ acetic acid and $33.5 \mathrm{ml}$ distal water]. For the transmitted electron microscope (TEM), tadpoles were fixed in $5 \%$ phosphate buffered $(\mathrm{pH} 7.2)$ glutaraldehyde for 8 hours and for molecular preparations tadpoles were deep frozen at $-80^{\circ} \mathrm{C}$.

\subsection{Histological Preparations}

For light microscope studies the staged tadpoles were fixed in Davidson's solution. Fixed tadpoles or tissues were processed routinely for paraffin embedding technique, transverse serial sections were cut at $5-7 \mu \mathrm{m}$, stained by Harris's Hematoxylin and Eosin stain (H \& E) according to Humason [18]. To distinguish between muscles and connective tissue Milligan's trichrome stain were used. Stained sections were examined using Ziess 
microscope and a digital color video camera (SONY, Cyber-shot, DSC-TX200/TX200V, 18.3 Megapixel).

\subsection{Histochemical Preparations}

The paraffin sections were used for the estimation of general carbohydrates. Polysaccharides represent the important parameter among the histochemical ones. For the demonstration of the polysaccharides status Periodic Acid Schiff's (PAS) technique was applied [16]. The positively stained materials have been proved to be glycogen as verified by PAS-technique with and without pretreatment with diastase.

In this regard, carbohydrates were first oxidized with $0.1 \%$ periodic acid; aldehyde groups (-HCO-HCO) were liberated from the glycol reagent producing a compound of magenta color with Schiff"s solution.

\subsection{Samples Preparations for Toluidine Blue Staining and TEM Examination}

Small pieces of $1 \times 1 \mathrm{~mm}$ size were taken from the liver, skin and eye balls were fixed in $5 \%$ cold buffer glutaraldehyde for $8 \mathrm{~h}$. The specimens were then repeatedly washed in phosphate buffer ( $\mathrm{pH} 7.2)$ and post fixed for 2 $\mathrm{h}$ in $1 \%$ osmium tetroxide $\left(\mathrm{OsO}_{4}\right)$ in phosphate buffer. The materials were then dehydrated rapidly in upgraded ethanol. Samples were embedded and cleared in propylene oxide for 60 minutes to remove remnants of alcohol. Thereafter, samples were embedded in propylene oxide: Epon $812(1: 1, \mathrm{v} / \mathrm{v})$ for 30 minutes. Samples were finally embedded into capsules containing pure epon 812 in a special polymerization incubator for three days (first day at $37^{\circ} \mathrm{C}$, second day at $45^{\circ} \mathrm{C}$ and the third day at $60^{\circ} \mathrm{C}$ ). Semithin sections of $0.5 \mu \mathrm{m}$ thickness were prepared using an ultra-microtome and stained with toluidine blue [19]. Sections were contrasted in uranyle acetate for 10 minutes and lead citrate for 5 minutes. Stained sections were examined and photographed by the TEM (Jeol 100X) at $80 \mathrm{Kv}$.

\subsection{Ethical Statement}

All experiments were carried out in accordance with the Egyptian laws and University guidelines for the care of experimental animals. Procedures of the current experiment have been approved by the Committee of the Faculty of Science of Assiut University, Egypt.

\section{Results}

\subsection{Liver}

\section{1) Stage 44}

The liver sections of tadpole at this stage showed a continuous mass of hepatocytes with almost centrally located nuclei. The eosinophilic hepatocytes contain relatively large nuclei with large nucleoli. Irregular and narrow blood sinusoids were seen among the hepatocytes. These blood sinusoids are lined with endothelial cells. Kupffer cells were seen at the vicinity of these endothelial cells. Melanomacrophages were noticed among the hepatocytes. Some nuclei showing mitotic figures, and some others undergoing regressive changes were demonstrated (Figure 1(a)).

\section{2) Stage 46}

At this stage the hepatocytes were arranged in strands. Hepatic cells were polygonal in shape with four or more surfaces. Acidophilic cytoplasm with centrally or eccentrically located large rounded deeply stained open face nuclei was noticed. Each nucleus has one or two nucleoli. Wide blood sinusoids filled with blood corpuscles were noticed (Figure 1(b) and Figure 1(c)). Haemopoitic tissues were seen near the periphery of the hepatic lobes and between the hepatocytes.

\section{3) Stage 48}

No extreme structural changes were noticed in the liver sections of tadpoles at this stage apart from greater vaculation in hepatocytes and sinusoidal dilatations (Figure 2(a)).

\section{4) Stage 52}

Examination of liver section prepared from the tadpole at this stage stained with Hematoxylin and eosin in addition to semithin sections showed apparent signs of rearrangement of hepatic strands in acini. The hepatic strands are separated from each other by blood sinusoids. These blood sinusoids are irregular and wide. The vacuolated hepatocytes have large open faced nuclei with their evident nucleoli. Pyknosis and apoptosis of some 

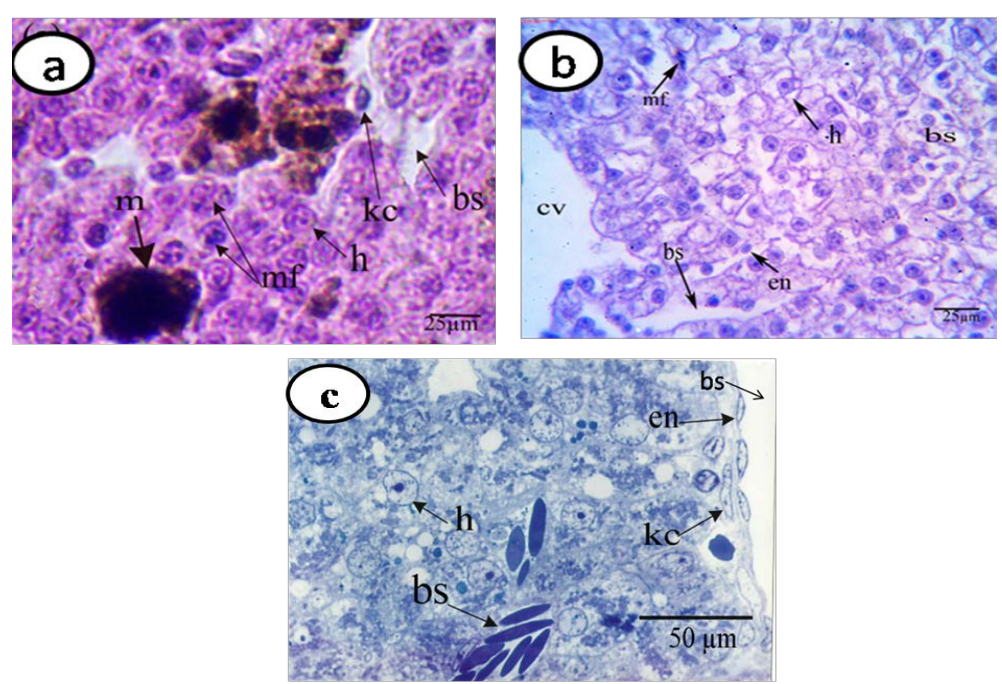

Figure 1. Sections and semithin section of the liver of Buforegularis tadpoles showing (a) stage 44, (b) and (c) stage 46, blood sinusoids (bs), central vein (cv), endothelial cells (en), hepatocytes (h), kupffer ( $\mathrm{kc}$ ), melanomacrophage (m), mitotic figure (mf), (a) and (b), H \& E, X 400 and scale bar $=25 \mu \mathrm{m})((\mathrm{c})$ Toluidine blue, $X 1000$ and scale bar $=10$ cells $\mu \mathrm{m})$.
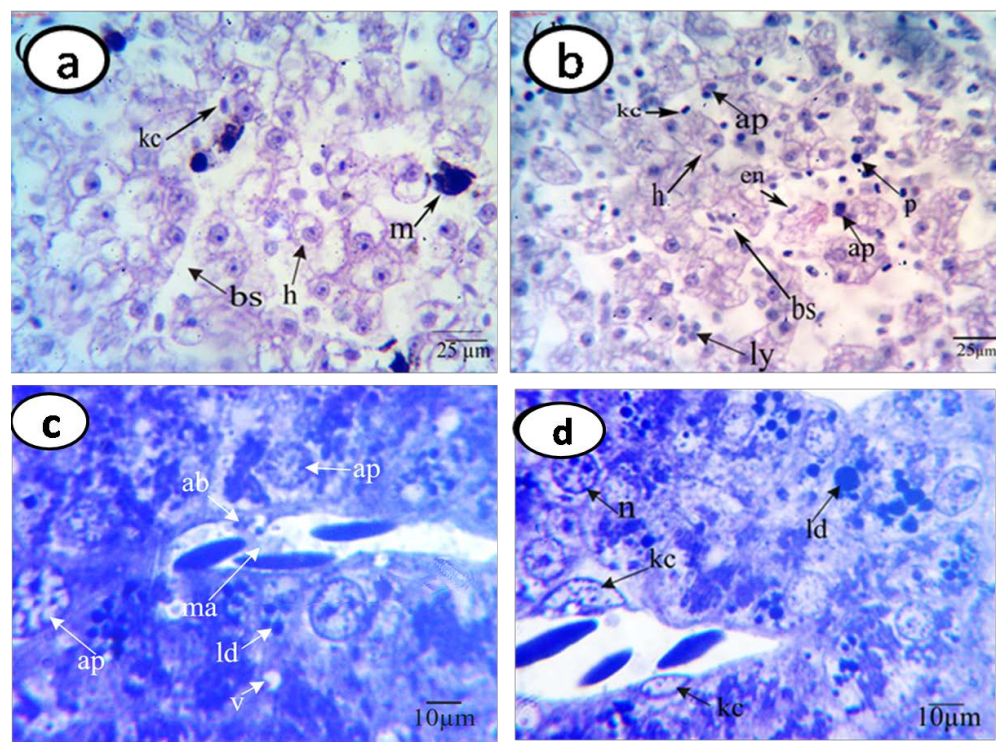

Figure 2. Sections and semithin sections of the liver of Buforegularis tadpoles showing (a) stage 48, (b), (c) and (d) stage 52, apoptotic nuclei (ap), apoptotic body (ab), dilated blood sinusoids (bs), endothelial cells (en), hepatocytes (h), kupffer cells (kc), lymphocyte (ly), melanomacrophage (m), pyknosis (p), vacuolated hepatocytes (v), lipid droplets (ld), macrophage cells (ma), nucleus (n), vacuoles (v), (a) and (b), H \& E, X 400 and scale bar $=25 \mu \mathrm{m})$, (c) and (d), Toluidine blue, $\mathrm{X} 400$ and scale bar $=10 \mu \mathrm{m})$.

nuclei were noticed. The disappearances of the borders between some cells were noticed. Kupffer cells increased in numbers and lymphocytes were observed inside the blood sinusoids as well as macrophages (Figure 2(b), Figure 2(c) and Figure 2(d)).

\section{5) Stage 54}

Examination of liver sections prepared from the tadpole at this stage stained with Hematoxylin and eosin sections showed the hepatic cells contained faintly stained eccentric nuclei and vacuolated eosinophilic cytoplasm. 
Dilatation of blood sinusoids was revealed. Large amount of leucocytes, red blood corpuscles and macrophage were noticed within these sinusoids. Kupffer cells increased in number, apoptosis was clearly seen at this stage. Reduction in the size and number of melanomacrophage was recorded (Figure 3(a)).

\section{6) Stage 55}

Examination of liver sections of tadpoles at this stage reflected advanced degree of degeneration as indicated by the vacuolization of the hepatocytes and the disappearance of boundaries between cells. Dilated blood sinusoids were filed with leucocytes. Large number of cells was shown in different stages of apoptosis. Reduction of pigment granules was observed. Numerous hematopoietic cells are seen in the sinusoidal capillaries of the hepatic strands (Figure 3(b)).

\section{7) Stage 64}

Sections of tadpole liver at this stage showed enlarged and vacuolated hepatocytes. These vacuoles showed much diversity in volume from large ones to many small ones. Cytoplasmic basophilic stained materials are localized around the nuclei while the rest of the cytoplasm stained pale with H\&E. The eccentric nuclei were of open face type with its visible nucleoli. Blood infiltrations were shown inside blood sinusoids (Figure 3(c)).

\section{8) Stage 66}

The whole sections of liver showed hypertrophied hepatocytes which are completely vacuolated. Most of cells contain one large vacuole. Few numbers of pyknotic nuclei of hepatocytes were seen. These nuclei took eccentric position. A little amount of basophilic cytoplasm around the open face nuclei and the cell borders were detected in other hepatocytes. Dilated blood sinusoids were noticed between the hepatocytes (Figure 3(d)).

\section{9) Milligan's Trichrome Stain}

Section at stage 66 stained by Milligan's trichrome stain showed the portal space with large blood capillaries which is extended into blood sinusoids, and sections of bile ducts and ductules. Large number of pyknotic nuclei was noticed. Hepatocytes showed hypertrophied and vacuolated cytoplasm, with eccentric nuclei which present in few numbers. Positively stained connective tissues among the hepatic cells were noticed (Figure 4(a) and Figure 4(b)).

\section{0) PAS Reaction}

PAS-technique revealed an intensive amount of glycogen in early stage (46) of development (Figure 5(a)), negatively reaction at stages 48 a 66 (Figure 5(b) and Figure 5(d)) and moderate amount of glycogen at stage
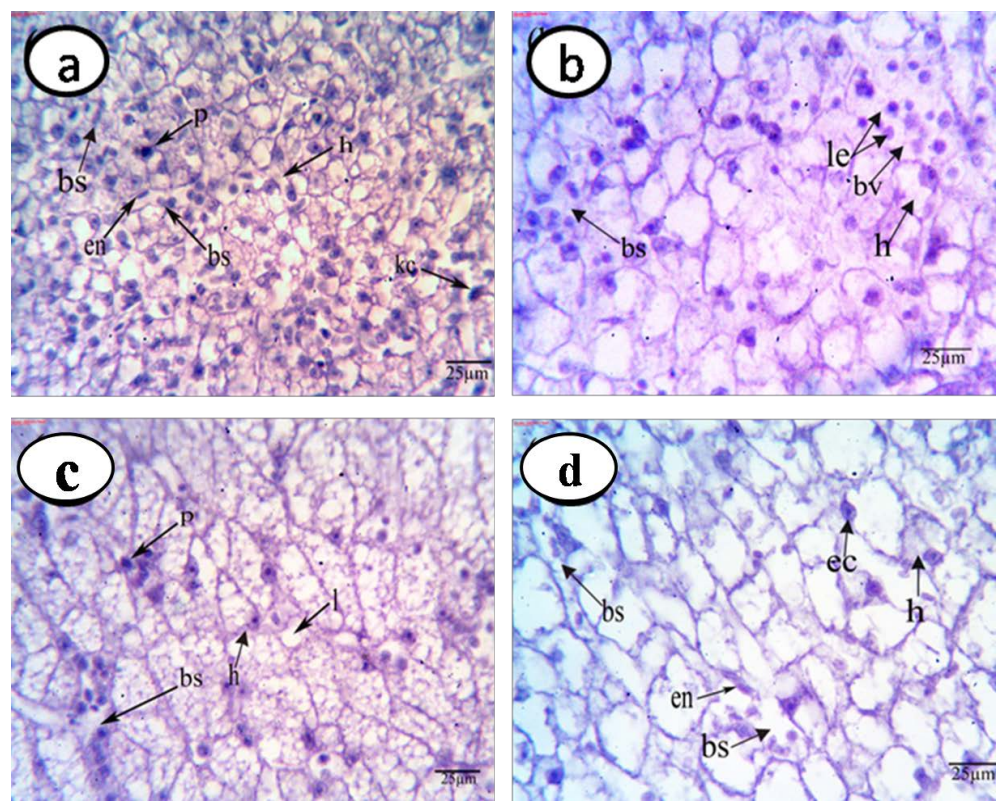

Figure 3. Sections of the liver of Bufo regularis tadpoles showing (a) stage 54, (b) stage 55, (c) stage 64, (d) stage 66, blood sinusoids (bs), blood vessel (bv), degeneration (de), eccentric nuclei (ec), endothelial cells (en), hepatocytes (h), kupffer cells (kc), leucocytes (le), lipid droplets (l), pyknosis (p), (H \& E, X 400 and scale bar $=25 \mu \mathrm{m}$ ). 

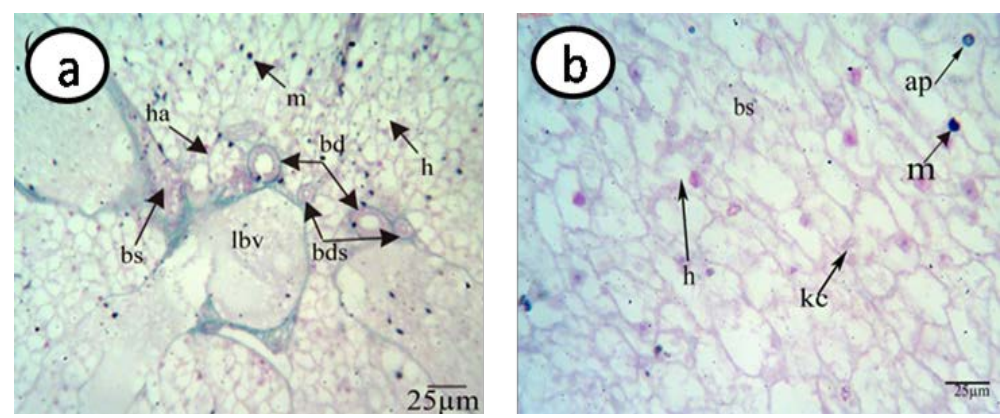

Figure 4. Sections of the liver of Bufo regularis tadpoles (stage 66) showing positively stained connective tissue, apoptotic nuclei (ap), bile duct (bd), bile ductiulies (bds), blood sinusoids (bs), hepatocytes (h), hepatic acini (ha), Kupffer cells (kc), large blood vessel (lbv), melanomacrophage (m) (Milligan's trichrome stain, (a) X 100, (b) X 400 and scale bar $=25 \mu \mathrm{m}$ ).
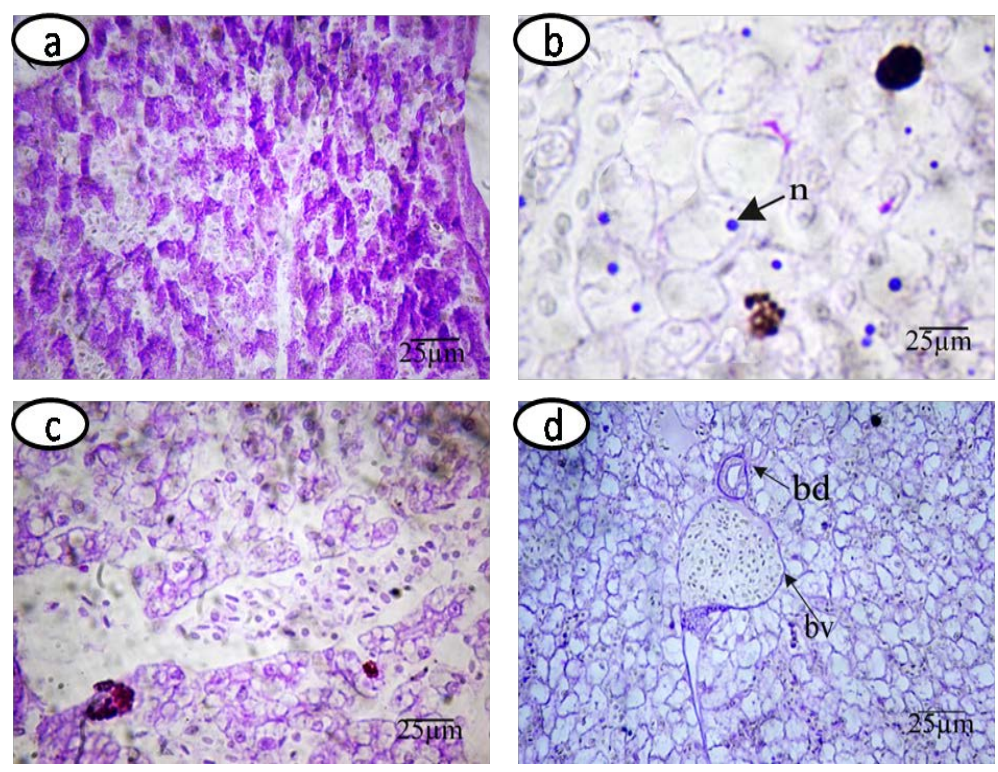

Figure 5. Sections of the liver of Bufo regularis tadpoles showing a huge amount of glycogen in (a) stage 46, negatively reaction in (b) stage 48 and (d) stage 66 , moderately amount of glycogen in (c) stage 52 , and positively stained nuclei in (b). Bile duct (bd), blood vessel (bv), nucleus (n) (PAS reaction without diastase enzyme, $X 400$ and scale bar $=25 \mu \mathrm{m})$.

52 (Figure 5(c)). In comparison between sections $5 \mathrm{~b}$ and $5 \mathrm{~d}$ the investigators noticed positively stained nuclei at stage 48 (Figure 5(b)) and negatively stained nuclei at stage 66 which might be due to apoptosis.

\subsection{Skin}

\subsubsection{Back Body Skin}

\section{1) Stage 44}

The skin consists of two layers epidermis and dermis; the first layer (epidermis) consisted of only one layer of cells based on the basement membrane. The basement membrane is too thin to be seen by light microscope. Some cells are oval in shape with oval nuclei and others are polygonal in shape with rounded nuclei. Epidermal mela-nophores appeared at this layer. The dermis consisted of collagenous layer appeared underneath the basement membrane separating the dermis from epidermis, loosely connective tissue, dermal melanophores and fibroblast cells (Figure 6(a)).

2) Stage 48 
The epidermis at this stage consisted of two types of cells: polygonal and skin cells. Epidermal melanin pigments dispersed within the epithelial cells. No drastic changes were noticed in the dermis at this stage apart from the increase in the dermal layer which contains blood capillary and dermal melanophores with dispersed melanin pigments within their processes (Figure 6(b)).

\section{3) Stage 54}

Apical layer of the epiderms contains micro processes which contains secretion, dermal layer of the skin more thick and contains loosely connective tissue with all contents as shown in (Figure 6(c)). Semithin section of the skin at stage 54 stained with Toluidine blue showing the epidermal layer cells of two types polygonal cells with faintly stained nuclei interposed with triangular cells (skein cells) and also divided cells were noticed. The dermisconsists of loose connective tissue separated from the epidermis by a collagen layer. Fibroblast found underneath this layer in contact with it. Blood capillaries, pigmented melanophores processes were seen (Figure $6(\mathrm{e}))$.

\section{4) Stage 55}

Epidermal layer of the skin contains two types of cells, the first one polygonal cells with oval nuclei and slightly basophilic cytoplasm, and the second one is skein cells (triangular cells) with dark triangular nuclei and dark basophilic cytoplasm, underneath this layer there was a collagenous fibers which is attached with fibroblast cells of the dermal layer, dermal melanophores also appeared in the dermal layer. This layer consisted of loose

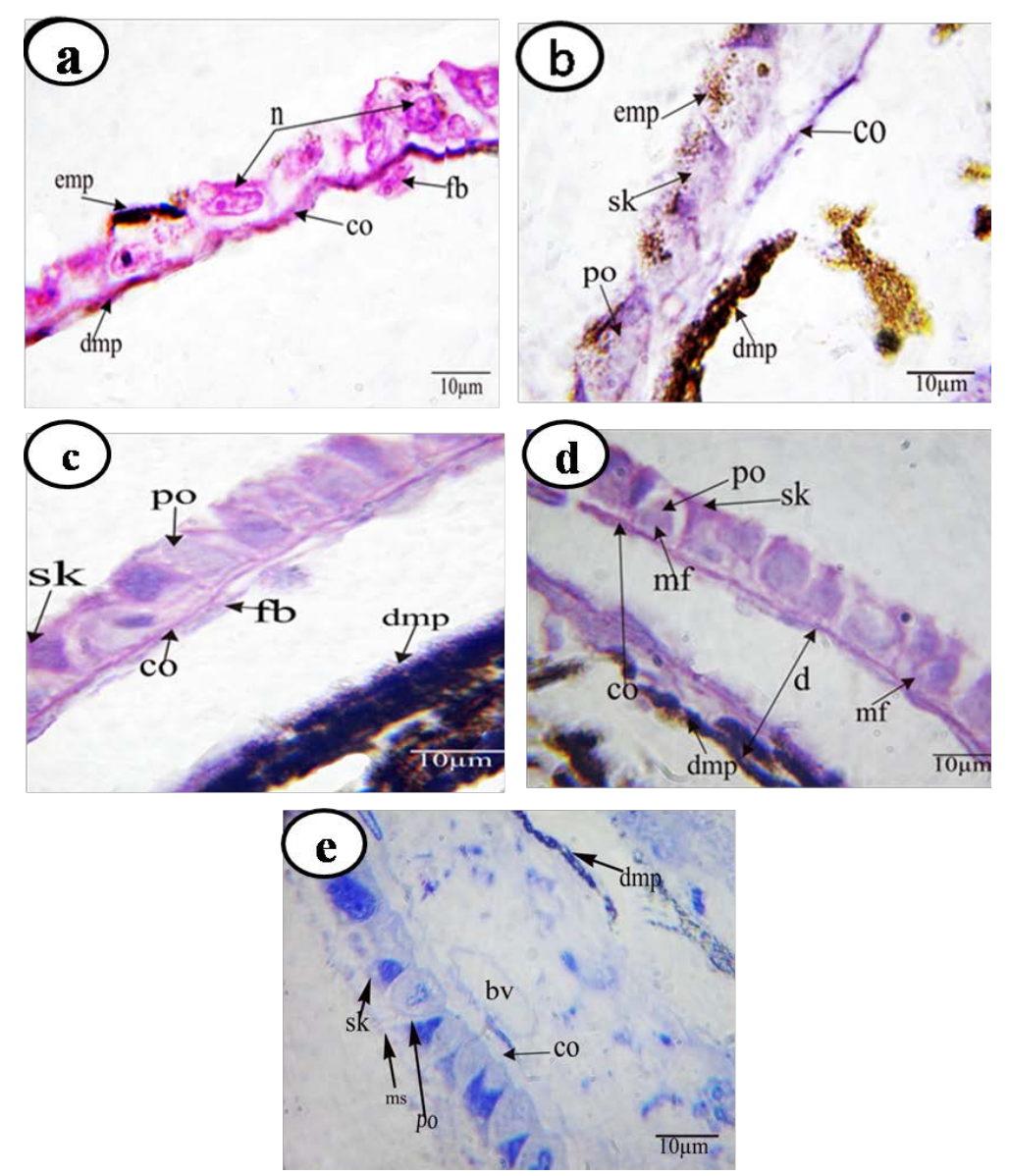

Figure 6. Sections and semithin section of the back body skin of Bufo regularis tadpoles stage 44, (b) stage 48, (c) and (e) stage 54, (d) stage 55 showing, blood vessel (bv), collagenous fiber (co), dermal layer (d), dermal melanophores (dmp), epidermal melanophores (emp), fibroblast cells ( $\mathrm{fb}$ ), mitotic figure (mf), mucous secretion (ms), nucleus (n), polygonal cells (po), skein cells (sk), (a)-(d), H \& E. X 1000 and scale bar $=10 \mu \mathrm{m})((\mathrm{e})$, Toluidine blue. $\mathrm{X} 1000$ and scale bar $=10 \mathrm{~mm})$. 
connective tissue with collagenous bundles and contains different types of connective tissue cells, blood and lymphatic vessels also shown in this layer (Figure 6(d)).

\section{5) Stage 64}

Epidermal layer appeared as stratified columnar epithelial tissue which contains basally located columnar cells with oval nuclei at the base (germinal layer). This layer is separated from the dermis by a basement membrane, too thin to be resolved by light microscope, polygonal cells with rounded nuclei in the middle, but in the outer surface columnar cells with oval nuclei; also skein cells appeared in the outer layer of the skin. Epidermal melanophores invaded the cells of this layer. Dermal layer contains two types of glands (mucous and poison glands). Mucous glands lined with cubic cells with rounded nuclei and contain mucous secretions. The poisonous glands are large and distinguished by their wall being formed of a syncytium, that is to say the cell membrane between the cells which compose it has disappeared so that their nuclei appeared in a continuous mass of protoplasm. Dermal layer also contains loosely and compact connective tissue. Collagenous fibers began to appear in compact layer at this stage, this layer contained different types of connective tissue cells and melanophores. Blood and lymph vessel also appeared as shown in (Figure 7(a) and Figure 7(b)).

\section{6) Stage 66}

Epidermal layer consists of stratified squamous epithelial tissue based on the basement membrane; dermal layer contains mucous and poisonous glands which are open by tube in the surface to excrete their secretion. Flattened faintly stained fibroblast cells with their flattened nuclei are aggregated underneath the basement membrane. Wide lymph vessel also appeared in the dermal layer. Thickness of epidermal and dermal layer increased (Figure 7(c) and Figure 7(d)).

\section{7) Milligan's Trichrome Stain}

Stage 54, as shown in Figure 8(a), section of skin showed dermal layer contains faintly staining collagenous fibers.

Stage 55, as shown in Figure 8(b), collagenous fibers are highly stained with Milligan's trichrome stain.

Stage 64 and Stage 66 are presented in Figure 8(c) and Figure 8(d) showing collagenous fibers strongly stained with Milligan' strichrome stain, also epithelial tissue which lined the glands stained with Milligan's trichrome. Connective tissue and glandular granules stained in light green by these stain. The granules stained light green also by this stain. Mucous glands negatively stained.
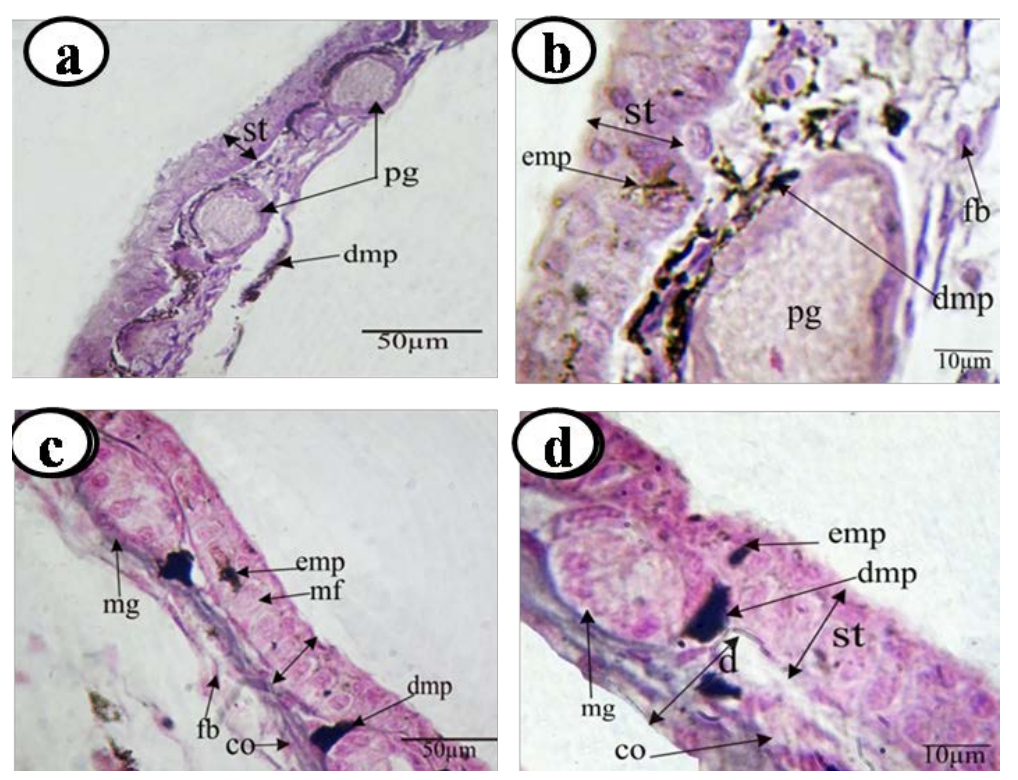

Figure 7. Sections of the back body skin of Bufo regularis tadpoles (a) \& (b) stage 64, (c) and (d) stage 66 showing, collagenous fibers (co), dermal melanophores (dmp), epidermal melanophores (emp), fibroblast cells (fb), dermal layer (d), mitotic figure (mf), mucous gland (mg), poisonous gland (pg) and stratified squmous epithelial tissue (st). H \& E, (a) and (c), X 400, scale bar = $50 \mu \mathrm{m}),(\mathrm{b})$ and (d), X 1000, scale bar $=10 \mu \mathrm{m}$. 


\section{8) PAS Reaction}

Section staining with PAS reaction: collagen layer, granules in the lumen of the poisonous gland, also around these glands and the connective tissues strongly stained with PAS (Figure 9).

\subsubsection{Tail Skin}

Comparing the histological structure of the tail skin at stage 44 with that at stage 64 we noticed that the epidermal layers in both consisted of one layer only. Stage 44 is as described previously in the back body skin. The epidermis was noticed to be consisted of only one layer of cells based on the basement membrane. The basement membrane is too thin to be resolved by light microscope. Some cells are oval in shape with oval nuclei and others are polygonal in shape with rounded nuclei (Figure 10(a)).

In histological structure of the tail skin at stage 64 the epidermis still also consisted of one layer of cells, this layer suffering from histolysis (Figure 10(b)).
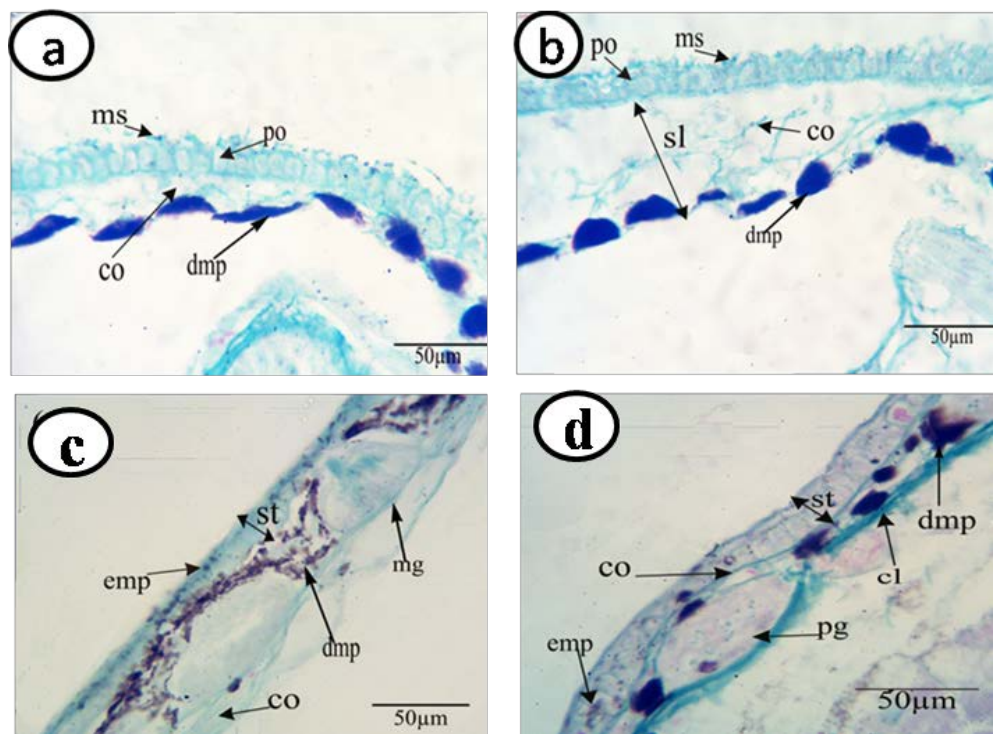

Figure 8. Sections of the back body skin of Bufo regularis tadpoles showing (a) stage 54, (b) stage 55, (c) stage 64, (d) stage 66, compact layer (cl), collagenous fibers (co), dermal melanophores (dmp), epidermal melanophores (emp), mucous secretion (ms), mucous gland (mg), poisonous gland (pg), polygonal cells (po), spongy layer (sl), stratified squamous epithelial tissue (st) (Milligan's trichrome stain, X 400 and scale bar $=50 \mu \mathrm{m}$ ).

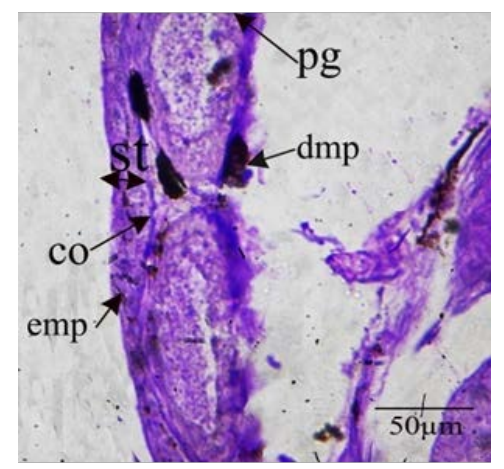

Figure 9. Section of the back body skin of Bufo regularis tadpoles (stage 66) showing positively stained granules with lumen. Collagenous fibers (co), dermal melanophores (dmp), epidermal melanophores (emp), poisonous gland (pg), stratified squmous epithelial tissue (st) (PAS reaction and H, X 400 and scale bar $=50 \mu \mathrm{m})$. 


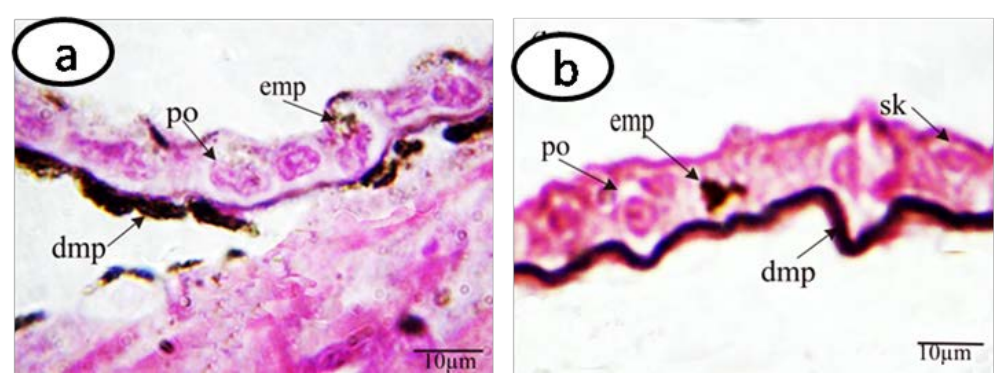

Figure 10. Sections of the tail skin of Bufo regularis tadpoles (a) Stage 44 showing epidermis and collagen layer, (b) Stage 64 showing break down and disintegration epithelial layer, as well as disappearance of the collagenous layer underneath the epidermis; dermal melanophores (dmp), epidermal melanophores (emp), polygonal cells (po), skein cells (sk) (H \& E, X 1000 and scale bar $=10 \mu \mathrm{m})$.

\section{Discussion}

In the present investigation the histogenesis of the liver of Bufo regularis tadpoles was studied from stage 44 (the beginning of feeding) up to metamorphosis climax by using the light microscope. The investigators noticed that the hepatocyte increased in size with the increase of the tadpole in age. The young tadpole had well developed hepatocytes. Many vacuoles with different sizes field the hepatocytes later and then these vacuoles fused together. Large amount of glycogen were observed in the liver cells during the active period of feeding stage (46), of the tadpoles and this amount dropped at stage (54) and lipid droplets were noticed in many hepatocytes. Olurin et al. stated that the formation of vacuoles in hepatocytes is due to the degeneration of cell membranes [18] and an imbalance between the rate of synthesis and utilization of substances in cells [19]. In contrast, Craw-shaw and Winkle mentioned that hepatocyte vacuolation representing fat and glycogen stores is a common histological finding in amphibians, and in many cases cannot be considered a pathological case [20]. Hepatic lipidosis is likely a consequence of the mobilization of fat depots in response to anorexia or starvation.

Griffiths stated that the transformation of the larval stomach into the adult organ takes place in a period between 7 and 10 days [21]. Dodd and Dodd (1976) noticed that during this period the animal stops to ingest food and keeps fasting [22]. Their findings were in coordination with the present investigation. Where we noticed moderate amount of glycogen at stage 64 and then suddenly declined at stage 66 . This may be in a synchrony with the emission of the forelimbs.

The number of melanomacrophages and Kuppfer cells decreased as development progressed. The number of pyknotic nuclei of the hepatocytes, macrophages and lymphocytes increased within the blood sinusoids near the hepatocytes as development progressed. In the present work dilatation in blood sinusoids was noticed. Sinusoidal dialation in the liver is attributed to the impairment of outflow of the hepatic veins [20].

[21] found the visual cells of developing tadpole contain glycogen in their nuclei which indicates pathological degeneration. In the present study the results coincide with the observations of [21], where glycogen granuules were seen in some nuclei of developing hepatocytes and disappeared at the commencement of metamorphosis. These nuclei may be considered in their way for apoptosis.

The histological transformation of amphibian liver during metamorphosis was studied by using the light and EM microscopes and DNA fragmentation in the tadpoles of Bufo regularis, Bufo viridis, Rana bedriagae and Ptychadena mascareniesis by [22]. They found in their study, the frequency of cell death was high variable depending on the developmental stage and the species of anuran amphibians used. Furthermore, apoptosis occurred in some species as a single wave; whereas at least two distinct waves could be detected in other species. In contrast, programmed cell death (apoptosis) in anuran amphibian embryos starts at the onset of gastrulation and then continues during gastrulation and neurulation [23]. During these early stages, apoptosis seems to occur without obvious peaks in time or space [23]. [22] mentioned that deletion of hepatic cells during embryonic development and spontaneous metamorphosis of the four tested species of anuran amphibians is accomplished by ultrastructurally typical apoptosis. The morphological appearance being essentially the same as those described in vertebrate embryos [24]-[29]. The phenomenon involves a stereo typed sequence of changes and begins with peripheral aggregation of nuclear chromatin. This is followed by nuclear fragmentation and cytoplasmic con- 
densation associated with prolific budding to produce membrane-bound apoptotic bodies of varying sizes. As is the case in other solid tissues, the actual processes of budding is rarely observed, possibly viable cells engulf the condensing ones [22] [30]-[33].

During metamorphosis and particularly the climax, severe cell death could be observed in the liver of the anuran species. Interestingly, cell death started before the tail desorption and it was observable over a long period from stage 58 (beginning of climax and tail regression), cell death in the liver was increasingly observed [22] [34] and [22] found heavy cell death affecting the liver prior to climax (stages 54 to 58). This observation fits with studies of hepatic resident macrophage activity [22] [35]-[37]. Macrophages initially appeared at early climax, increased rapidly in number during muscle regression and reach peak density at late climax [36] [38] [39] and these results are similar to our observation, where we observed many macrophages in the sinusoidal lumen near the hepatic cells at stage 54 as shown in the semithin sections.

In the present work haematopiotic tissues were noticed within the blood sinusoids and underneath the hepatic capsule. The liver plays an important role in hematopoiesis in the amphibian embryo. Histiocytic and erythroblastic cell types predominate, but lymphocytic and granulocytic precursors are also present. After metamorphosis, other organs such as the bone marrow take over this role, but residual activity may be seen in adult amphibians, particularly beneath the liver capsule. The liver also has a significant immune function. In addition to leukocytopoiesis, the large population of melanomacrophages and the related Kupffer cells that line the sinusoids act both as phagocytes and in antigen recognition [40]. In the postembryonic stages, they scavenge embryonic erythrocytes [40]-[42]. Melanin is a complex polymer that can absorb and neutralize free radicals and other toxic agents [40] [43]. Melanomacrophages are focal accumulations of pigmented macrophages in liver, spleen and more rarely in kidneys of fishes [44] and also in liver of frogs [45]. These may contain four types of brown to black pigments, namely melanin, lipofuscin, ceroid, and hemosiderin/ferritin. Melanomacrophage proliferation has been associated with several natural factors, such as normal aging, starvation, and infectious diseases [40]. Hepatic melanomacrophages appear to increase in number also with antigenic stimulation, and with otherfactors causing tissue breakdown [41]. Increased density of these macrophages has also been observed in experimentally treated fish [44], amphibians [45], and naturally polluted frogs [46].

Amphibian metamorphosis provides an excellent model for studying the physiological cell death as in keratinization or terminal differentiation of body epidermis (diffpoptosis) and tail tissue regression serves as a model of programmed cell death (PCD) (apoptosis) [14]. Additionally, amphibian metamorphosing skin is one of the best studied examples of an organ that remodels in response to thyroid hormones. Modification of ionic calcium concentration also markedly alters the pattern of proliferation and differentiation in amphibian epidermal cells in vitro [10]. Remodeling of existing organs is accomplished by the death of larval cells and the growth and differentiation of adult stem cells [47] [48].

Amphibian epidermis changes its nature during metamorphosis from a noncornified bilayered epidermis to a stratified epidermis with actively dividing basal cells and a keratinized outer layer [49].

The epidermis is one of many amphibian tadpole tissues that are remodeled at metamorphosis [50] [51]. The tadpole epidermis consists of two to three cell layers in contact with a cellular collagen lamella. The premetamorphic dermis consists of the collagen lamella, an adjacent single layer of subepithelial fibroblasts, and melanophores [50]. These results are in accordance with the present work. As thyroid hormone (TH) concentration raises in the tadpole during metamorphic climax the outer two cell layers of the epidermis are thought to die by apoptosis [52]. The basal cells of the tadpole epidermis are progenitors for the adult frog epidermis. At metamorphosis the subepithelial fibroblasts secrete proteolytic enzymes such as collagenase- 3 and invade the collagen lamella, the dermis thickens, and adult skin glands form [50].

In the present work we observed that the epidermis of tadpole back body skin consisted of one layer at stage 44 and the tail epidermis at stage 64 consisted only of a disintegrated one layer. [13] mentioned that during metamorphosis the tissue develops adult skin in the body region and histolyzes larval skin in the tail region. These results are in accordance with the present work.

[10] [48] [53] [54] stated that at early stages of development, there are no differences between the tail and body epidermis. As metamorphosis progresses at late stages, basal cells appeared in the body epidermis which proliferate and differentiate into germinative basal cells of the adult-type of keratinized epidermis. These results are in agreement with the present work.

In the present work using light microscope, we noticed two types of cells forming the body skin in the tadpoles. These cells were skein and polygonal cells rested on the basement membrane. [10] described skein cells 
as the cells which have large intracellular bundles of tonofilaments known as Figure of Eberth' which are connected by numerous microvilli.

Tail dermis probably loses the ability to develop the normal structure of epidermis-dermis junction during metamorphosis [55] spontaneous metamorphosis, the initial sign of degeneration of tail skin is detected in the dermal components, followed by degeneration in the epidermis [55]. This result is in agreement with the present investigation, where we noticed that there was no any componants of the connective tissues in the late stage of development of the tail dermis such as collagene layer underneath the epidermis, fibroblast or blood vessels as those observed in the epidermis of the body skin.

In the present work we noticed at stage 64 two types of glands, mucous and poisonous glands. In agreement with [56] described two types of glands in the amphibian skin, both of them alveolar (or acinar): mucous glands, and granular or serous glands. Other types have been described in certain anuran species [57].

Genesis of the cutaneous glands has been studied in the anurans [58] [59]. These glands originated from the epidermis. In the basal portion of this tissue, there arose groups of cells, generated perhaps through the division of a single precursor cell [60]. These groups form the gland primordia or gland rudiments [58] [61]. The cells of these primordia then divide, migrate in the direction of the stratum spongiosum of the dermis [62] and differentiate in the cell layers of the epithelial portion of the gland alveolus [56] [61].

The granular glands produce a toxic or repellent secretion with an effect on various vertebrate species; this is one of the principal elements in amphibian defense. In the course of the secretory cycle, these cells usually lose their limits and turn into a syncytium [56] [63]. In anuran species, the granular glands, in the present work named poisonous glands, possess secretory layer, syncytial in its nature [64]. In various species of apodans and urodelans, the secretory layer consists of individualized cells [56] [63] at least at the beginning of the secretory cycle [56] [63]. The granular glands are generally made up of a gland alveolus formed by a secretory layer covered externally by a myoepithelial layer. This contractile layer is related with the extrusion of glandular products [56] [63].

\section{Conclusion}

In conclusion, the result obtained from this study indicates that the amphibian metamorphosis is a complex process that has been speculated to involve histogenesis in most of body organs especially liver and skin as target organs in the present investigation. Histochemical studies display different values during amphibian development and can be used as an investigation tool for the evaluation of the histological changes of the Egyptian toad during metamorphosis.

\section{Acknowledgements}

This research carried out at Zoology Department, Faculty of science, Assiut University, Assiut, Egypt and funded by the Ministry Higher Education from Libyan Government.

\section{References}

[1] Wester, P.W. and Canton, J.H. (1991) The Usefulness of Histopathology in Aquatic Toxicity Studies. Comparative Biochemistry and Physiology, 100, 115-117.

[2] Thophona, S., Kruatrachuea, M., Upathama, E.S., Pokethitiyooka, P., Sahaphongb, S. and Jaritkhuanc, S. (2003) Histopathological Alterations of White Seabass, Lates calcarifer in Acute and Subchronic Cadmium Exposure. Environmental Pollution, 121, 307-320. http://dx.doi.org/10.1016/S0269-7491(02)00270-1

[3] Scharfettner-Kochanek, K., Wlaschek, M., Brenneisen, P., Schauen, M., Blaudschun, R. and Wenk, J. (1997) UV-Induced Reactive Oxygen Species in Photocarcinogenesis and Photoageing. Journal of Biological Chemistry, 378, $1247-$ 1257.

[4] Gernhofer, M., Pawet, M., Schramm, M., Müller, E. and Triebskorn, R. (2001) Ultrastructural Biomarkers as Tools to Characterize the Health Status of Fish in Contaminated Streams. Journal of Aquatic Ecosystem Stress and Recovery, 8 , 241-226. http://dx.doi.org/10.1023/A:1012958804442

[5] Akiyoshi, H. and Inoue, A.M. (2012) Comparative Histological Study of Hepatic Architecture in the Three Orders Amphibian Liver. Comparative Hepatology, 11, 1-8. http://dx.doi.org/10.1186/1476-5926-11-2

[6] Hoffman, J. and Katz, U. (1998) Glyconeogenesis and Urea Synthesis in the Toad Bufo viridis during Acclimation to Water Restriction. Physiological Zoology, 71, 85-92. http://dx.doi.org/10.1086/515886 
[7] Osman, A.H., Pfeiffer, C.J. and Asashima, M. (1991) Liver Uhrastructure and a New Cell Type in the Japanese Newt, Cynops pyrrhogaster. European Journal of Morphology, 29, 255-270.

[8] Goldblatt, P.J., Hampton, J.A., DiDio, L.N., Skeel, K.A. and Klaunig, J.E. (1987) Morphologic and Histochemical Analysis of the Newt (Notophthalmus viridescens) Liver. The Anatomical Record, 217, 328-338. http://dx.doi.org/10.1002/ar.1092170403

[9] Rappaport, A.M. (1967) Diseases of the Liver. In: Schiff, L., Ed., Anatomic Considerations, 2nd Edition, Lippincott Company-Asian Edition Hakko Co. Ltd., Philadelphia, 1-46.

[10] Menon, J. and Wahrman, M. (2001) Ultrastructure Observations on Effect of Different Concentrations of Calicum and Thyroxine in Vitro and Larval Epidermal Cells of Rana catesbelana Tadpoles. In Vitro Cellular \& Developmental Biology-Animal, 37, 283-292.

[11] Lindeman, V.F. (1929) Integumentary Pigmentation in the Frog, Rana pipens, during Metamorphosis, with Especial Reference to Tail-Skin Histolysis. Physiological Zoology, 2, 255-268.

[12] Clausen, H.J. (1930) Rate of Histolysis of Anuran Tail Skin and Muscle during Metamorphosis. Biological Bulletin, 59, 199-210. http://dx.doi.org/10.2307/1536989

[13] Kinoshita, T., Sasaki, F. and Watanabe, K. (1986) Regional Specificity of Anuran Larval Skin during Metamorphosis: Dermal Specificity in Development and Histolysis of Recombined Skin Grafts. Cell and Tissue Research, 245, 297304. http://dx.doi.org/10.1007/BF00213935

[14] Pan, K.M., Baldwin, M., Nguyen, J., Gasset, M., Serban, A., Groth, D., Mehlhorn, I., Huang, Z., Fletterick, R.J. and Cohen, F.E. (1993) Conversion of $\alpha$-Helices into $\beta$-Sheets Features in the Formation of the Scrapie Prion Proteins. Proceedings of the National Academy of Sciences of the United States of America, 90, 10962-10966. http://dx.doi.org/10.1073/pnas.90.23.10962

[15] Schreiber, A.M. and Brown, D.D. (2003) Tadpole Skin Dies Autonomously in Response to Thyroid Hormone at Metamorphosis. Proceedings of the National Academy of Sciences of the United States of America, 100, 1769-1774. http://dx.doi.org/10.1073/pnas.252774999

[16] Sedra, S.N. and Micheal, M.I. (1961) Normal Table of the Egyptian Toad, Bufo regularis Reuss, with an Addendum on the Standardization of the Stages Considered in Previous Publications. Ceskoslovenská Morfologie, 9, 333-351.

[17] Sayed, A.H., Elballouz, A.I. and Wassif, E.T. (2014) Molecular Characterization on the Early Developmental Stages of the Egyptian Toad Bufo regularis Reuss. Open Journal of Genetics, 4, 343-354. http://dx.doi.org/10.4236/ojgen.2014.45031

[18] Humason, G.L. (1979) Animal Tissue Techniques. 4th Edition, W.H. Freeman, San Francisco.

[19] Gupta, P.D. (1983) Ultrastructural Study on Semithin Section. Science Tools, 30, 6-7.

[20] Tanaka, M. and Wanless, I.R. (1998) Pathology of the Liver in Budd-Chiari Syndrome: Portal Vein Thrombosis and the Histogenesis of Veno-Centric Cirrhosis, Veno-Portal Cirrhosis, and Large Regenerative Nodules. Hepatology, 27, 488-496. http://dx.doi.org/10.1002/hep.510270224

[21] Glucksman, A. (1940) Development and Differentiation of the Tadpole Eye. British Journal of Ophthalmology, 24, 153-178. http://dx.doi.org/10.1136/bjo.24.4.153

[22] Saad, A.H., Aziz, A.A., Yahie, A. and El-Ghareeb, A. (2009) Programmed Cell Death in the Liver of Different Species of Anuran Amphibians during Metamorphosis. Australian Journal of Basic and Applied Sciences, 3, 4644-4655.

[23] Hensey, C. and Gautier, J. (1998) Programmed Cell Death during Xenopus Development: A Spatio-Temporal Analysis. Developmental Biology, 203, 36-48. http://dx.doi.org/10.1006/dbio.1998.9028

[24] Glucksmann, A. (1951) Cell Death in Normal Vertebrate Ontogeny. Biological Reviews, 26, 59-86. http://dx.doi.org/10.1111/j.1469-185X.1951.tb00774.x

[25] Bellairs, R. (1961) Cell Death in the Chick Embryo as Studied by Electron Microscopy. Journal of Anatomy, 95, 5460.

[26] Farbman, A.I. (1968) Electron Microscope Study of Palate Fusion in Mouse Embryos. Developmental Biology, 18, 93116. http://dx.doi.org/10.1016/0012-1606(68)90038-9

[27] Manasek, F.J. (1969) Myocardial Cell Death in the Embryonic Chick Ventricle. Journal of Embryology and Experimental Morphology, 21, 271-284.

[28] Webster, D.A. and Gross, J. (1970) Studies on Possible Mechanisms of Programmed Cell Death in the Chick Embryo. Developmental Biology, 22, 157-184. http://dx.doi.org/10.1016/0012-1606(70)90012-6

[29] Mottet, N.K. and Hammar, S.P. (1972) Ribosome Crystals in Necrotizing Cells from the Posterior Necrotic Zone of the Developing Chick Limb. Journal of Cell Science, 11, 403-414.

[30] Kerr, J.F.R. (1973) Some Lysosome Functions in Liver Cells Reacting to Sublethal Injury. In: Dingle, J.T., Ed., Lyso- 
somes in Biology and Pathology, Vol. 3, North-Holland, Amsterdam, 365-394.

[31] Tsuchiya, Y., Murai, S. and Yamashita, S. (2005) Apoptosis-Inhibiting Activities of BIR Family Proteins in Xenopus Egg Extracts. FEBS Journal, 272, 2237-2250. http://dx.doi.org/10.1111/j.1742-4658.2005.04648.x

[32] Hasebe, T., Kajita, M., Fujimoto, K., Yaoita, Y. and Ishizuya-Oka, A. (2007) Expression Profiles of the Duplicated Matrix Metallo-Proteinase-9 Genes Suggest Their Different Roles in Apoptosis of Larval Intestinal Epithelial Cells during Xenopuslaevis Metamorphosis. Developmental Dynamics, 236, 2338-2345. http://dx.doi.org/10.1002/dvdy.21252

[33] Saelim, N., Holstein, D., Chocron, E.S., Camacho, P. and Lechleiter, J.D. (2007) Inhibition of Apoptotic Potency by Ligand Stimulated Thyroid Hormone Receptors Located in Mitochondria. Apoptosis, 12, 1781-1794. http://dx.doi.org/10.1007/s10495-007-0109-1

[34] Estabel, J., Mercer, A., Konig, N. and Exbrayat, J. (2003) Programmed Cell Death in Xenopuslaevis Spinal Cord, Tail and Other Tissues, Prior to, and during, Metamorphosis. Life Sciences, 73, 3297-3306. http://dx.doi.org/10.1016/j.lfs.2003.06.015

[35] Purrello, M.N., Scalia, M., Corsaro, C., Di Pietro, C., Piro, S. and Sichel, G. (2001) Melanosynthesis, Differentiation, and Apoptosis in Kupffer Cells from Rana esculenta. Pigment Cell Research, 14, 126-131. http://dx.doi.org/10.1034/j.1600-0749.2001.140208.x

[36] Frangioni, G., Atzori, A., Balzi, M., Fuzzi, G., Ghinassi, A., Pescosolido, N., Bianchi, S. and Borgioli, G. (2006) Thyroid and Hypoxic Stress in the Newt Trituruscarnifex. Journal of Experimental Zoology Part A, 305, 225-232. http://dx.doi.org/10.1002/jez.a.268

[37] Frangioni, G., Santoni, M., Bianchi, S., Franchi, M., Fuzzi, G., Marcaccini, S., Varlani, C. and Borgioli, G. (2005) Function of Hepatic Melanogenesis in the Newt Trituruscarnifex. Journal of Experimental Zoology Part A, 303, 123131.

[38] Zorn, A.M. and Mason, J. (2001) Gene Expression in the Embryonic Xenopus Liver. Mechanisms of Development, 103, 153-157. http://dx.doi.org/10.1016/S0925-4773(01)00341-0

[39] Szalewicz, A., Strzelczyk, B., Sopel, M. and Kubicz, A. (2003) The 35 kDa Acid Metallophosphatase of the Frog Ranaesculenta Liver: Studies on Its Cellular Localization and Protein Phosphatase Activity. Acta Biochimica Polonica, 50, 555-566.

[40] Crawshaw, G.J. and Weinkle, T.K. (2000) Clinical and Pathological Aspects of the Amphibian Liver. Seminars inAvian and Exotic Pet Medicine, 9, 165-173. http://dx.doi.org/10.1053/ax.2000.7133

[41] Corsaro, C., Scalia, M., Blanco, A.R., Aiello, I. and Sichel, G. (1995) Melanins in Physiological Conditions Protect against Lipoperoxidation. A Study on Albino and Pigmented Xenopus. Pigment Cell Research, 8, 279-282. http://dx.doi.org/10.1111/j.1600-0749.1995.tb00675.x

[42] Sichel, G., Scalia, M., Mondio, F. and Corsaro, C. (1997) The Amphibian Kupffer Cells Build and Demolish Melanosomes: An Ultrastructural Point of View. Pigment Cell Research, 10, 271-287. http://dx.doi.org/10.1111/j.1600-0749.1997.tb00687.x

[43] Zapata, A.G. and Cooper, E.L. (1990) The Immune System: Comparative Histophysiology. John Wiley and Sons, Chichester.

[44] Couillard, C.M. and Hodson, P.V. (1996) Pigmented Macrophage Aggregates: A Toxic Response in Fish Exposed to Bleached-Kraft Mill Effluent? Environmental Toxicology and Chemistry, 15, 1844-1854. http://dx.doi.org/10.1002/etc.5620151027

[45] Loumbourdis, N.S. and Vogiatzis, A.K. (2002) Impact of Cadmium on Liver Pigmentary System of the Frog Rana ridibunda. Ecotoxicology and Environmental Safety, 53, 52-58. http://dx.doi.org/10.1006/eesa.2002.2153

[46] Fenoglio, C., Boncompagni, E., Fasola, M., Gandini, C., Comizzoli, S., Milanesi, G. and Barni, S. (2005) Effects of Environmental Pollution on the Liver Parenchymal Cells and Kupffer-Melanomacrophagic Cells of the Frog Rana esculenta. Ecotoxicology and Environmental Safety, 60, 259-268. http://dx.doi.org/10.1016/j.ecoenv.2004.06.006

[47] Yoshizato, K. (1992) Death and Transformation of Larval Ceils during Metamorphosis of Anura. Development, Growth \& Differentiation, 34, 607-612.

[48] Izutsu, Y., Kaiho, M. and Yoshizato, K. (1993) Differential Distribution of Epidermal Basal Cells in the Anuran Larval Skin Correlates with the Skin's Regionspecific Fate at Metamorphosis. Journal of Experimental Zoology, 267, 605-615. http://dx.doi.org/10.1002/jez.1402670608

[49] Shimizu-Nishikawa, K. and Miller, L. (1991) Calcium Regulation of Epidermal Cell Differentiation in the Frog Xenopus laevis. Journal of Experimental Zoology, 260, 165-169. http://dx.doi.org/10.1002/jez.1402600205

[50] Fox, H. (1984) Amphibia Morphogenesis. Humana Press, Clifton, New Jersey. http://dx.doi.org/10.1007/978-1-4612-5302-0 
[51] Dodd, M.H.I. and Dodd, J.M. (1976) The Biology of Metamorphosis. In: Lofts, B., Ed., Physiology of the Amphibia, Vol. 3, Academic Press, New York.

[52] Kerr, J.F.R., Harmon, B. and Searle, J. (1974) An Electron-Microscope Study of Cell Deletion in the Anuran Tadpole Tail during Spontaneous Metamorphosis with Special Reference to Apoptosis of Striated Muscle Fibers. Journal of Cell Science, 14, 571-585.

[53] Robinson, D.H. and Heintzelman, M.B. (1987) Morphology of Ventral Epidermis of Rana catesbeiana during Metamorphosis. Anatomical Record, 217, 305-317. http://dx.doi.org/10.1002/ar.1092170310

[54] Izutsu, Y.,Yoshizato, K. andTochinai, S. (1996) Adult-Type Splenocytes of Xenopus Induce Apoptosis of Histocompatible Larval Tail Cells in Vitro. Differentiation, 60, 277-286. http://dx.doi.org/10.1046/j.1432-0436.1996.6050277.x

[55] Kinoshita, T.,Medof, M.E. and Nussenzweig, V. (1986) Endogenous Association of Decay-Accelerating Factor DAF with C4b and C3b on Cell Membranes. Journal of Immunology, 136, 3390-3395.

[56] Toledo, R.C. and Jared, C. (1995) Cutaneous Granular Glands and Amphibian Venoms. Comparative Biochemistry and Physiology Part A, 111, 1-29.http://dx.doi.org/10.1016/0300-9629(95)98515-I

[57] Fujikura, K., Kurabuchi, S., Tabuchi, M. and Inoue, S. (1988) Morphology and Distribution of the Skin Glands in Xenopuslaevis and Their Response to Experimental Stimulations. Zoological Science, 5, 415-430.

[58] Bovbjerg, A.M. (1963) Development of the Glands of the Dermal Plicae in Rana pipiens. Journal of Morphology, 113, 231-243. http://dx.doi.org/10.1002/jmor.1051130209

[59] Vanable, J.W. (1964) Granular Gland Development during Xenopuslaevis Metamorphosis. Developmental Biology, 10, 331-357. http://dx.doi.org/10.1016/0012-1606(64)90049-1

[60] McGarry, M.P. and Vanable Jr., J.W. (1969) The Role of Thyroxine in the Formation of Gland Rudiments in the Skin of Xenopuslaevis. Developmental Biology, 20, 426-434. http://dx.doi.org/10.1016/0012-1606(69)90024-4

[61] Delfino, G. (1977) Ildifferenziamentodelleghiandole granulose cutanee in larve di Bombinavariegatapachypus (Bonaparte) (Anfibio, Anuro, Discoglosside). Ricerca al microscopioottico e al microscopioelettronico. Archivio Italiano di Anatomia e di Embriologia, 82, 337-363.

[62] Verma, K. (1965) Regional Differences in Skin Gland Differentiation in Rana pipiens. Journal of Morphology, 117, 73-85. http://dx.doi.org/10.1002/jmor.1051170105

[63] Delfino, G., Brizzi, R. and Calloni, C. (1990) A Morphofunctional Characterization of the Serous Cutaneous Glands in Bombinaorientalis (Anura: Discoglossidae). Zoologischer Anzeiger, 225, 295-310.

[64] Delfino, G. (1991) Ultrastructural Aspects of Venom Secretion in Anuran Cutaneous Glands. In: Tu, A.T., Ed., Handbook of Natural Toxins, Vol. 5, Marcel Dekker Inc., New York, 777-802. 